\title{
The Effectiveness of Public Sector Innovation in Improving Local Competitiveness (Studies in Surabaya Singgle Window: Innovations for Business License Services)
}

\author{
Falih Suaedi ${ }^{1}$, Sri Juni Woro Astuti ${ }^{2}$ \\ \{suaedifalih@yahoo.com ${ }^{1}$, srijuniworo@uwp.ac.id ${ }^{2}$ \} \\ Social and Political Science Faculty, Airlangga University ${ }^{1}$, Social and Political Science Faculty, Wijaya \\ Putra University ${ }^{2}$
}

\begin{abstract}
In the more dynamic changing global environment, improving local and national competitiveness can be seen as one of the strategic entry points. Competitiveness is one of the parameters of successful development and independence of a region that is directly related to the level of community welfare. Achieving the independence and competitiveness of a nation must begin with the creation of a conducive precondition to ensure the smooth and holistic improvement of the innovation climate. Therefore the local and national government must be able to create and enhance its competitiveness through the development of strategic innovations. This study wants to analyze what factors are inhibiting and support the effectiveness of innovation system developed in Surabaya city government. The purpose of this study is to conceptualize an effective model of innovative system development at the local government level based on best practice from the Surabaya city government. The method used is a qualitative descriptive method. The data collected by a combination of questionnaires, documents, and in-depth interviews. Interviews were conducted on informants consisting of bureaucrats, community leaders, politicians, and academicians. The results showed that Surabaya city government has succeeded in developing an innovation strategy effectively. Most of the innovations that have been developed are supported by technology-based information systems. But there are still some obstacles in the application of information technology used, so the city of Surabaya still need to work to improve its innovation strategy to be able to realize its vision as a city that is globally competitive
\end{abstract}

Keywords: Innovation, Competitiveness, Local development.

\section{Introduction}

The success of the development program is largely determined by the development management that has been executed, starting from planning, implementation, evaluation, and follow-up of the evaluation. Once there is mismanagement in one of the stages of development will hamper the process of achieving the expected results. Therefore, the principles of prudence and precision are needed in the process of development management. But empirically, limitations in the development management process is still frequently encountered and became the main obstacle in achieving development goals. This is reflected in not achieving yet the success indicators of local and national development from year to year. One important aspect of 
development success indicators is how to improve competitiveness both on a national and regional scale. Competitiveness in this context is the ability of the government to develop the economic and social abilities of an area that can improve community welfare and able to face the dynamics demands of competition in the global era.

From the global competition index data shows that Indonesia's competitiveness among 148 countries is still relatively less competitive even decreased from rank 34 in 2015-2016 to 37 in the 2016-2017 as shown in the table below.

Table 1. Global Competitiveness Index[1]

\begin{tabular}{ccccc}
\hline Country & $2013-2014$ & $2014-2015$ & $2015-2016$ & $2016-2017$ \\
\hline Switzerland & 1 & 1 & 1 & 1 \\
Singapore & 2 & 2 & 2 & 2 \\
United State & 5 & 3 & 3 & 3 \\
Nederland & 8 & 8 & 8 & 5 \\
Germany & 4 & 5 & 5 & 4 \\
Malaysia & 24 & 20 & 20 & 18 \\
Thailand & 37 & 31 & 31 & 32 \\
Indonesia & 38 & 34 & 34 & 37 \\
Philippines & 59 & 52 & 52 & 47 \\
Vietnam & 70 & 68 & 68 & 56 \\
Cambodia & 88 & 95 & 95 & 61 \\
\hline
\end{tabular}

Competitiveness indicators also are seen from the ease of doing business level. If compared with Singapore, Malaysia, Thailand, Vietnam, and Brunei Darussalam, business convenience in Indonesia is still far behind. In 2014, the ranking of the ease of doing business in Indonesia was ranked 120, rising slightly from the year 2013, which was ranked 128 . The rating is far below other Asian countries in 2014, Malaysia was ranked 6, Taiwan 16, Thailand 18, Brunei 59, and Philippines 108. But Indonesia, the last in the ASEAN-6 group, gained 11 notches, from 120 in 2015 to 109 in 2016, and in 2017 it increased to rank 91 [2]. But still bellow than Thailand, Vietnam, Malaysia, and other Asian countries. Therefore, Indonesia should immediately improve itself in all sectors to increase their competitiveness.

Among several successful development indicators, local and national competitiveness can be seen as a strategic entry point that boosts economic growth, which in turn will improve the community welfare in developing countries. By increasing the competitiveness of the local economy, the level of social welfare is expected to be better. Therefore, the local governments should be able to formulate a grand design for local and national competitiveness enhancement in their respective regions, even in a global context through innovations strategy. However, not all local governments in Indonesia are able to develop and implement innovations.

Many innovations have been developed, but these innovations are not followed up with government policy. The new findings resulting from the various research and development institutions, that intended to solve the real problems of economic and social development, many innovations in public organizations were not successfully adopted and implemented. This is because there is no comprehensive innovation system that integrating various economic, social, political, and technological factors that encourage the development of a systematic and problemsolving oriented innovation. However, some local governments have succeeded in encouraging local innovation, so as to resolve economic and social problems of the local community, and in turn, can increase the growth of the local economy to become more competitive. One of them is the Surabaya city government, which is able to bring the local development became more 
successful. So that the Surabaya city deserves to be a pilot project in the application of innovation in the public sector.

Surabaya city is the capital of East Java Province, Indonesia, as well as the largest metropolitan city in the province. Surabaya is the second largest city in Indonesia after Jakarta. The city is located $796 \mathrm{~km}$ east of Jakarta, or $415 \mathrm{~km}$ northwest of Denpasar, Bali. Surabaya is located on the northern coast of eastern Java Island and facing the Madura Strait and the Java Sea. Surabaya has an area of about $350.54 \mathrm{~km}^{2}$ with a population of 2,853,661 inhabitants.

Surabaya city government has won many awards, both national and international level in recognition of the success of building the city, as well as human beings. Many achievements have been inscribed Surabaya city government, both at the regional level, national to international. Here are some achievements of Surabaya city at the international level and bring it into a world-class city: 1) Citynet Award Best City Participation Categories in the Asia Pacific in 2012. The city of Surabaya received this award for being able to invite "stakeholders" involved in sustainable urban development, 2) UN Award for Bungkul Park. One of the parks in Surabaya, Bungkul Park, won the International Award from the United Nations (UN) in the form of "The 2013 Asian Townscape Sector Award" submitted in Japan on November 2013. The award also has the support of four world organizations, namely UN Habitat Regional Office for Asia and The Pacific, Asia Habitat Society, Asia Townscape Design Society, and Fukuoka Asia Urban Research Center. Bungkul park became the only park in Indonesia that won the United Nations award. This park is considered worthy of the award because it has a social function, culture, recreation, and education. In addition, the park also features various support facilities, such as jogging tracks, children's playground, wireless Internet access, amphitheater, and skateboarding arena. 3) Future Gov Award 2013. The city of Surabaya proved able to surpass the major cities and other developed countries with incised achievements in the Asia Pacific level through the event Future Gov Awards 2013. Surabaya city government won the title in two categories, namely, Data Center and Data Inclusion. Data Center category is achieved through Media Center of Surabaya City Government, while Data Inclusion through Broadband Learning Center (BLC). 4) Socrates Award category of the future city achieved in April 2014. Socrates Award is a prestigious event initiated by the Europe Business Assembly (EBA). It is an independent company in the UK that pays attention to economic, social, and cultural development. 5) By 2016 Gallup World Poll, a worldwide organization that examines public attitudes toward political, social, and economic problems, puts Surabaya in second place as the happiest city.

At the national level, Surabaya won the first smart city award in Indonesia in 2015. The assessment in the coronation of Smart City is seen from the number of problems successfully resolved by a municipal or regional government. There are many more awards that prove the success of its government leader Tri Rismaharini who became mayor since 2010. The proudest of innovations in the public service is the Surabaya Single Windows (SSW) licensing system as an innovation that provides benefits to the community. In addition to the licensing service becomes faster, SSW also been proven to improve efficiency. In addition, there are many more awards that have been obtained as proof of the successful development of the Surabaya city government.

All these achievements are inseparable from the success of Surabaya city government in applying innovation policy and public service innovation. Considering the many obstacles to the implementation of innovation in the public sector as described above, this study wants to analyze what factors are support and inhibiting the effectiveness of innovation system developed in Surabaya city government since Surabaya has run best practices in implementing innovations in the public sector. 


\section{Literature Review}

\subsection{Innovation System and Competitiveness}

Innovation as a new idea applied to initiate or improving a product or process and services. Innovation in the context of product innovation or innovation services industry plays an important role in improving the competitiveness of a region. The simplest definition is that public sector innovation is about new ideas that work at creating public value. The ideas have to be at least in part new (rather than improvements); they have to be taken up (rather than just being good ideas); and they have to be useful [3]

However, the development of innovation needs to be designed so that these innovations can be adopted and implemented in a sustainable manner, which in turn can contribute substantially to improving the welfare of society. It required a conceptual innovation development strategy in a comprehensive manner in a system of innovation. The system, according to the innovation [4] is an element and relationships that interact to produce, diffuse, and use new knowledge and beneficial economically. So the innovation system is a national system that includes elements and relationships housed or rooted in a state boundary. In another section, he also said that the innovation system is a social system in which learning, searching, and extracting / exploring the activity of central, which involves interaction between people / communities and reproduction of knowledge individually or collectively through remembering[5]. The innovation system is an overall economic factor, social, political, organizational, and other factors that influence the development, diffusion, and use of innovation[6]. Thus, the innovation system basically involves the determinant of innovation [5]. National innovation system that set of distinct institutions which jointly and individually contribute to the development and diffusion of new technologies and which provides the framework within which governments form and implement policies to influence the innovation process. As such it is a system of interconnected institutions to create, store and transfer the knowledge, skills and artefacts which define new technologies.

Some that make the basic principles of innovative regional and or national strategy development include strategic thinking and consistent with long-term frameworks. Local Innovation strategy is the regional priority agenda and is an integral part of the regional development strategy. The innovative regional strategy is a strategic policy of enhancing regional competitiveness, focusing on local best potential and open to creative ideas that benefit regional progress, and setting clear goals and rational achievements. This viewpoint provides a platform and a framework for us both individually and collectively about the importance of systemic / holistic approaches, nonlinearities, and the importance of interactions, partnerships and synergies of various elements of the system and the importance of the government's role in generating the coherence of policies Related to the so-called innovation policy. The system of innovation is essentially a system or a unity of various elements (actors, institutions, linkages, networks, interaction processes, and policies) that affect the direction of development and speed of innovation, the diffusion of innovation and learning processes that occur in a country or region. This system covers the fields of science, technology, and innovation. This innovation system must be continuously built or reinforced dynamically [7].

Regional competitiveness is now one of the central issues, especially in order to secure employment stability, and take advantage of external integration (global trends), and sustainability of local and regional prosperity and prosperity growth. As also confirmed by another study that "Local Economic Development is about competitiveness - it is about companies thriving in competitive markets and locations thriving in a competitive, globalized world." 
Innovation policy that runs comprehensively as well as the collaboration among development actors is a key factor in improving the competitiveness of the local and national levels. Development of the local innovation system is one of the main strategies in the national innovation system that embodies the process of strengthening the interaction between components of the innovation system. Innovation system emphasizes the importance of ongoing interaction between many processes where all these processes run in parallel and reinforce one another through a positive feedback mechanism. If this type of feedback is ignored, whether by policy makers or by the employer, then it is likely to cause a failure in the innovation process in the entire system[8]. The innovation systems approach, which identifies the driving force of innovation such as government organizations, research centres, and universities and its contextual background that shapes the innovative behaviour of actors such as history, culture, socio-economic conditions - is considered a useful framework in this context for elaborating effective policy intervention[9].

An innovation system is a comprehensive policy approach required to change behavior in order to improve productivity and performance. It was considered as a framework that facilitated monitoring and managing the elaboration of policy. The system of innovation provides key analytical insights to assist the policy-making process using a more holistic perspective. In the process of comprehensive public policy, need to pay attention to all aspects of the policy environment itself.

\subsection{Constraints of innovation in government organizations}

The problem that arises is how to encourage the innovation of local governments because some parties have noticed the local government's unwillingness to innovate as a result of legal cases faced by regional heads or local officials. The lack of innovation in local governance resulted from the concerns of local leaders to make a breakthrough for fear of involvement in legal issues, given that discretion is often synonymous with actions that are not in accordance with the rules.

Jamil Khatib in his presentation slide titled Capacity Building: Barriers to Knowledge Adoption (2013) mentions four innovation constraints: do not know, can not do, not willing, and not allowed. Meanwhile, another researcher suggested eight obstacles to innovation as follows[3]:

1) Reluctance to close down the failing program or organization. Meaning, a program or even an organizational unit that clearly shows failure will be better closed down and replaced with a new program that is more promising.

2) Over-reliance on high performers as a source of innovation. The notion that develops today, there is a tendency that innovation is only possible if there is a strong figure and has a high consistency. Once the figure disappears, all the renewal initiatives are gone.

3) Technologies available but constraining cultural or organizational arrangement. Often innovation fails not because there is no technical support, but rather because of the tradition or organization policy that is not pro-innovation.

4) No rewards or incentives to innovate or adopt innovations. The award in order to foster employee motivation to give the best for the institution is mere fairness. Thus, innovation and appreciation are two inseparable sides. The ability to innovate cannot be regarded as a mediocre or normal performance but should be viewed as something special that deserves to be rewarded.

5) Poor skills in active risk or change management. However, the aspect of skills is critical to the success of innovation. Regardless of the motivation of employees and the 
environment is conducive but not supported by adequate skills, then innovation will stop as a discourse.

6) Short-term budget and planning horizons. Budget support is a necessity to innovate. The experience of many developed countries that budgeted research and innovation funds up to $3 \%$ of GDP has provided evidence that innovation-based technological advances are the result of long-term investments. Therefore, the development of innovation both within the organizational and national sides must be well planned not only in an annual perspective but also in the medium and long term perspective.

7) Delivery pressures and administrative burdens. In ex-colonial countries, administrative aspects often become obstacles in the management of certain affairs including innovation. The relationship between the state and the society or between leaders and employees is often based on the basis of distrust. As a result, for a small business (e.g., licensing service) must include large requirements, lengthy procedures, and involving multi-layered actors.

8) Culture of risk aversion. The unwillingness to bear the impact of choice is psychological as well as a cultural constraint for progress. Risk is seen as something to be avoided and even shunned, not something that presents a new, more energetic challenge that must be faced.

\section{Methods}

The type of this research is qualitative, and the approach used is a descriptive approach. One important factor in research activities is to determine the focus of research to limit the study so that the object to be studied is not widened and too broad. Based on the problems that have been formulated, the focus of this research is the implementation of the concept of sound governance in order to improve the competitiveness of regions. This research takes place in Surabaya city government, considering Surabaya as one of the local government in Indonesia, which has successfully applied various policy innovation in order to improve its local competitiveness. Most data collection is done through interviews with several key informants who come from various elements of government apparatus, community, and businessmen. Other than that, data retrieval is also done through secondary data search to obtain more comprehensive data. Then the data are analyzed qualitatively with an interactive approach, starting from data collection, data reduction, data confirmation, and verification.

\section{Results and Discussions}

\subsection{Surabaya Single Window (SSW): Innovations for Business License Services}

Negative stigma is always inherent when dealing with bureaucracy in the processing of business licenses in Indonesia. Complicated procedures, length of time management, and uncertain costs always arise when faced with the complexity of the bureaucracy. In the era of regional autonomy, the Surabaya city government quickly respond to public complaints related to the handling of business license, especially since the leadership of Tri Rismaharini Mayor. Under the leadership of Tri Rismaharini, Surabaya City Government trying to change the negative image that is embedded in the community. She assumes that this negative habit occurs because people always face to face directly with the bureaucracy representatives, where if you 
want the documents quickly completed, there must be bribe money that must be paid. To prevent this the Surabaya City Government made a system so that citizens do not have to face to face with the officers so that it can eliminate the system of corruption, collusion, and nepotism within the bureaucracy.

In the era of local autonomy, the local government has full authority to carry out the mission of development in accordance with the potential of the region and the real needs of the local community. Public welfare is one indicator of the success of local and national development. Moreover, entering the era of global competition, the challenge of both national and local governments increasingly severe. The government does not just have to build up public confidence that increasingly faded, but also has to create innovations in order to raise the value of the local competitiveness both nationally and internationally. An innovation will work well if planned thoroughly and comprehensively[10]. In turn, it will encourage the growth of local economies and improve community welfare.

From several policy innovations that have been taken by Surabaya city government, one aspect that gets big attention is the policy in investment activity. Considering the right policies in the field of investment, will brings a considerable economic impact, such as the increase in the number of goods and services, the creation of added value, usage of labor, and other economic resources, the increase in incomes, and as a source of local revenue in the form of taxes and levies. Investment development activities are closely related to the achievement of regional economic development objectives. The conception of regional economic development has a purpose: (1) create jobs; (2) achieving regional economic stability; (3) developing a diverse economic base.

With the development of various innovations in the public service sector, Surabaya city becomes one of the successfully local governments in East Java Province in improving community welfare. Surabaya's economic growth gradually increased since 2009 which reached $5.53 \%, 7.09 \%$ in $2010,7.56 \%$ in $2011,7.62 \%$ in $2012,7.34 \%$ in 2013 . But decreased in 2015, which only reached $5.97 \%$ and by 2016 it slightly increased up to $6 \%$.

The decline of Surabaya economic growth in 2015 is inseparable from the decline of Indonesia's national economic growth that only $5 \%$. Some of the factors contributing to the slowdown in economic growth are, among others, due to the increase of the city's minimum wage that is resulting in many firms being shocked by this policy. As a result, they decrease the amount of production. This also automatically affects the local economy, as well as the rise in fuel oil prices, also contributed to the slowdown in national and local economies. Although economic growth has decreased, the city of Surabaya is the second best city in Indonesia with a score of 89.85 after Bandung City that reached scored 92. The scores achieved put the Surabaya city into the best city of East Java province [11].

With improving economic growth, the level of unemployment at Surabaya city also decreased, in 2015 unemployment rate 85.432 people and in 2016 fell to 83,000 people. This reduction in unemployment is partly due to being absorbed in the small and medium business sector. Growth of small and medium enterprises in Surabaya is quite fantastic, for five years from 2010 to 2015 increased by $300 \%$.

Such rapid growth cannot be separated from the reform and innovation in business license services for small and medium entrepreneurs. The Mayor of Surabaya, Tri Rismaharani, has cut, simplified, and granted free licenses for Small and Medium Enterprises in Surabaya. Even SME licenses can be delivered directly to the home of SMEs. For this reason, the Surabaya City Government based on Surabaya Mayor Regulation number 28 of 2013 explains that in order to improve licensing and non-licensing services, which is more effective, efficient and transparent, electronic licensing service is implemented. In March 2013, Surabaya began launching an 
integrated service called Surabaya Single Window (SSW). This service will facilitate the citizens of the city as well as foreigners and business actors who want to invest in Surabaya. SSW is one of the implementation of e-Government in Surabaya which firstly related to the community directly and will continue to be developed. Through this system, the people who are taking care of the licensing will only conduct face-to-face with a system that is integrated with the internet or online. With the existence of this system is expected negative image about the procedure of business license will disappear by itself. Because it is online, then the people who will take care of the permit does not need to come to the office. Even from home can be done. The whole process uses electronic data. So, all the necessary documents stayed in scan and uploaded to Surabaya Single Window (SSW) system.

\subsection{Factors That Inhibit and Support The Innovation System In Surabaya City}

\section{Policy Environment Factors}

The policy environment in the broadest sense includes economic, social, political, and organizational factors that influence the process of policy formulation and become a key driver for the effectiveness of policies implementation. An environment that is concerned with the effect of policy implementation (context of the policy) is as follows: sufficient resources, power, and commitment of Actors Involved.

The most important resources from the local government side are the financial resources, competent personnel, and leadership commitment. Financial resources in Surabaya city has increased every year since 2012 in which the budget revenue of about 1,331 trillion, in 2013 increase to 1,498 trillion, in 2014 up to 1,893 trillion, and in 2015 to 2,120 trillion (41\% increased from 2014). Its indicates that Surabaya city has sufficient financial resource for financing such innovations. In terms of personnel/official resources at Surabaya city also constantly improve professionalism through various strategies such as training, continuing education, seminars, and conferences, as well as comparative studies to other areas which are considered to be successful and can be used as a comparison in increased welfare and public services. Whereas, power, in this case, is the authority of local governments to regulate and define their own regional development policies in accordance with local priorities. In local development planning policy, it is clear that the commitment of the local government is very high to continuously develop a variety of innovative public services and public policy innovation. The achievement of Surabaya city government would not be separated from the leader's commitment over the last few years, especially in the era of the leadership of Mayor Risma (2010-2015). The leadership commitment has been evidenced by the innovation of public services and policies carried out consistently and continuously in the last few years, as described below:

"affirming the commitment of the service providers in improving the quality of public services, creating innovative services, add-setting service standards (SPP), an increase the number of recipients ISO 9001: 2008, complaints resolution services, information technology development and the establishment of public service quality improvement team" (in-depth interview, Juni 2015).

With the high commitment of the leadership, Surabaya was awarded "Indonesia Attractiveness Index," which the assessment is based on four criteria divided between the investment climate, public services, infrastructure, and tourism. Furthermore, Surabaya also earned the best district in Indonesia with a total index highest was 84.43 in relation to the progress of regional competitiveness for investment interest, infrastructure availability, tourism Improvement, and public services satisfaction. At this level, Surabaya city has the highest index 
compared to other districts in Indonesia. At East Java Province, Surabaya city has successfully defeated other districts, included in this category are Sidoarjo, Banyuwangi, Malang, Gresik, Jember, and Tuban (the name of districts in East Java Province). Stigma about public service that was known to be very rigid and complicated will be transformed through the efforts of Surabaya government to adapt citizen charter pattern or approach in the public service implementation that puts users of the service as the center of attention. One indicator of the local progress lies in the public's satisfaction.

\section{Diffusion of Innovations}

The success of an innovation is also determined by the diffusion of the innovation process, which is how innovation is communicated through certain channels over time among a group of a particular community. One stage in the diffusion of the innovation process is the development of a social network or social system that involves all stakeholders. The social system is a set of different functional units and bonded in collaboration to solve problems in order to achieve shared goals [12].

One of the success factors of innovation in Surabaya city, due to the support of all stakeholders, especially the community. Such as an innovation in the field of health called "Community Resource Based Activities for Public Health Effort" is the most successful innovation programs among other innovative programs in Indonesia, because these programs were fully supported by the local community. Surabaya city government has conducted a series of approaches and technical policy in order to encourage such innovation. The approach used by the local government, among others are: 1) Community based, placing the community as decision-maker and responsible for activities performed in the program. 2) Participatory, involving all parties in the community or stakeholders. 3) Gender equality, giving the opportunity to anyone, men and women involved in every decision-making, implementation, and evaluation of the programs. 4) Sustainability, changes on healthy behaviors that occur and the availability of supporting infrastructure and facilities in order to provide benefits, so the program is considered to be continued to achieve the expected quality of life. 5) Transparency and accountability, the program is done in an open, reliable, accurate, and accountable [13].

Whereas technical policies that support the diffusion of innovation, among others: Such as the training for officers, agents of change and several community cadres to drive the public health service called "Posyandu", assisted by health workers. The next process of diffusion of innovation is strengthening cooperation among stakeholders, which consisting of all parties contributing to the sustainability of this program. Each party has a balanced role and equally important, and intertwined each other, so as to form a particular social system. With the formation of this social system, the innovation program will be internalized in routine activities that are an integral part of this social system. The integrated service post for health is a form of community development programs that most effective. As it grows, the true cadres are required to be more proactive in the organization so that more productive in generating great ideas that benefit the community. Communities in Surabaya city, especially health cadres have proved it. They have demonstrated active participation that can generate 20 innovation programs that are very beneficial in improving community health particularly for mothers and children.

In order to strengthen the social system to support the diffusion of the innovation process, Surabaya regents also create a mechanism for direct communication with rural communities called "sambang desa" (villages visitation). Visiting the village is one of the means to communicate in terms of public aspirations and to know directly the problems faced by each village. The regent said that: "With a direct dialogue with the people, we get to know what 
people need, so that in preparing the future development programs in line with expectations and is needed by the community" (in-depth interview, February 2016).

\subsection{The Implementation of innovations and Its Implication to The Local Competitiveness}

The diffusion of innovations also needs to be balanced between the ability to communicate well of the whole apparatus of service personnel and the ability to implement the innovation program. This communication is not limited to the process of delivering the message alone, but all the actions that have the potential of communication, such as the performance of the officers in conveying or catch the public interest. All of which is included in the intellectual capital that is not visible (intangible). These intangible factors will be perfect with the support aspect of the visible (tangible), for example the existence of a conducive agencies conditions in terms of public acceptance, spatial arrangement, and neatness. Public services Innovation in Surabaya city is trying to combine these two interests the tangible and intangible factors.

For example, in the application of innovation in Integrated Licensing Services Office, the tangible and intangible factors combined such as by designing a special counseling or complaints room that serves to mediation and troubleshooting space with two-way communication method between service workers and the community as users. This approach is done solely to compensate the community demands to obtain better public services from year to year due to an increase in public awareness of their rights as governments constituent.

The implications of their innovation policies in various aspects, ranging from increased licensing services with an integrated system, tax penalty exemption on building permit or occupancy permit, the development of Majapahit village as an efforts to maximizing the potential of authentic tourism attraction, and innovation in term of community based in health care efforts has had a positive impact on the business climate and production in Surabaya. It has been proven with GDP increasing from year to year. In term of economic growth, Surabaya city realized by $6.36 \%$ in 2014, while the Human Development Index realized 73.83 (upper middle class). Gross Regional Domestic Product (GRDP) Surabaya city is also increasing every year, it shows that public welfare has improved from year to year.

\section{Gross Regional Domestic Bruto}

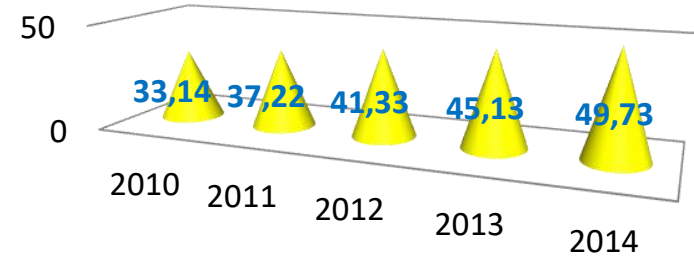

Fig 1. Per Capita GRDP of Surabaya city (Million Rp) 2010-2014

With their wide range of innovative services, in particular licensing service, has brought positive implications for the development of a business climate in Surabaya city. The interest of investors is also higher to start a business there, there are more than 50 companies have opened factories in Ngoro Industrial Park. In addition to large-scale enterprises, small and medium business climate also continue to grow and improve their competitiveness not only in the scope 
of the national market but also in regional and international markets. Some small and medium industries that have a high potential for export products is the industry of shoes, bags and purses, handcrafted silver, brass castings where their products have been marketed in various countries such as in Europe, Saudi Arabia, and Asian countries. The development of the business climate, then a positive impact also on the level of community welfare is reflected in declining numbers of income gap of 0,28 in 2012 and 2013 to 0,27 in 2014. Over all performance achievements the Surabaya city government, finally in 2015 was awarded the best district by Indonesia's attractiveness Index, based on four assessment criteria namely: investment, public services, infrastructure, and tourism. In the context of investment, Surabaya city has a high fascination for investors. Both for foreign and domestic investment. In 2014 the number of foreign investors amounted to 38 that absorb a total of 5,478 workers, while there are 18 domestic investors with a workforce amounted to 1,483 people. Whereas in 2015, the level of investment in Surabaya regent was ranked fifth out of 33 number of counties/cities in East Java province.

\section{Conclusion}

Improving the local and national competitiveness is the primary development mission for decades in Indonesia that has not received serious attention. Indonesia still lags behind when compared to neighboring countries, particularly in terms of ease of doing business, which in turn may inhibit the business and investment climate within the country. Therefore, national and local governments are required seriously and quickly to catch up with developing various innovative strategies and formulate policies that support the implementation of such innovations. Since the last few years after the Reformation era, national and local governments began to develop policies aiming to encourage the development of business and investment climate in Indonesia. In line with the government policy to increase national and local competitiveness, the Ministry of State Apparatus Empowerment and Bureaucratic Reform has issued a policy called one agency-one innovation aiming to improve the community welfare and encourage the investment climate.

However, in order an innovation can be implemented effectively, there is need to build innovation systems that institutionalize innovation in the community. An effective innovation system is strongly influenced by the degree of involvement of each element in the social system and the process of knowledge transfer among them so that innovation can be understood, executed, evaluated and developed by themselves. The results of this study show how the development of the innovation system, which then had an impact on improving the local competitiveness, not only at the national level but also in the international market. The innovation system reviewed from environmental policy, the diffusion of innovation, and implementation of innovation, which is then associated with the indicators of competitiveness achieved in Surabaya city.

In this study, the policy environment that has been studied are sufficient resources, power, and commitment of Actors Involved. These three factors provide significant implications for the development and sustainability of the innovations developed in Surabaya. Meanwhile, the diffusion of innovation is an important step in the institutionalization of innovation, the approach used is a community-based approach that is accompanied with a technical approach in the form of programs to increase human resource capacity. Thus the innovation system developed in Surabaya city has been operating effectively. 


\section{References}

[1] A. Briefing, “Asia Improves International Competitiveness," 2013. [Online]. Available: http://www.asiabriefing.com/news/2013/09/asia-improves-international-competitiveness/.

[Accessed: 01-Mar-2019].

[2] Doingbusiness.org, "www.pdf," 2017. [Online]. Available: www.doingbusiness.org/ data/exploreeconomies/Indonesia. [Accessed: 01-Mar-2019].

[3] G. Mulgan and D. Albury, "Innovation in the Public Sector," London, 2003.

[4] B.-Å. Lundvall, Ed., National Innovation Systems: Towards a Theory of Innovation and Interactive Learning. London: Pinter Publishers, 1992.

[5] Wikipedia, "Sistem informasi," 2019. [Online]. Available: https://id.wikipedia.org/wiki/Sistem_inovas. [Accessed: 01-Mar-2019].

[6] C. Edquist, "The Systems of Innovation Approach and Innovation Policy: An account of the state of the art," in DRUID Conference, Aalborg, June 12-15, 2001, under theme: 'National Systems of Innovation, Institutions and Public Policies,' 2014.

[7] T. A. Taufik, "Pengembangan Sistem Inovasi Daerah: Perspektif Kebijakan. Pusat Pengkajian Kebijakan Teknologi Pengembangan Unggulan Daerah dan Peningkatan Kapasitas Masyarakat," Jakarta, 2005

[8] R. A. A. Suurs, Motors of Sustainable Innovation--Towards a Theory on the Dynamics of Technological Innovation Systems. Utrecht: GeoMedia, Faculty of Geosciences, Utrecht University, 2008.

[9] M. Iizuka, "Innovation systems framework: still useful in the new global context?," 2013.

[10] S. J. W. Astuti and D. W. Prasetyono, "Inovation Development To Increase Local Competitiveness (Case in Mojokerto)," in IAPA International Conference at Unima Tondano, September 27-29, 2015, 2015.

[11] I. A. Awards, "Daftar Pemenang Tahun 2017," 2017. [Online]. Available: http://www.indonesiaattractiveness-award.com/the_winner.html. [Accessed: 01-Mar-2019].

[12] M. Rogers, Everett, Diffusions of Innovations, Fifth Edit. Simon \& Schuster Publisher, 2003.

[13] P. Surabaya, "No Title," 2015. [Online]. Available: Surabaya.go.id. 
Arnold, D. david (2014), The Critical Issues Affecting Asia, http://asiafoundation.org/ 2014. artikel internet

Astuti, SJW and Prasetyono,DW, Inovation Development To Increase Local Competitiveness (2015), paper presented on IAPA International Conference at Unima Tondano, September 27-29.

Edquist (2001), The Systems of Innovation Approach and Innovation Policy: An account of the state of the art,

Mulgan, Geoff and Albury, David (2003), Innovation in the Public Sector, London (http://www.sba.oakland.edu)

Huggins, R., Creating UK Competitiveness Index: Regional and Local Benchmarking (2003), Regional Studies journal, Vol. 37.1, pp. 89-96

Daftar Pemenang Tahun 2017 Indonesia's Attractiveness Awards dalam Situs http://www.indonesiaattractiveness-award.com/the_winner.html

Kjell Underlid (2012). Autonomy and Poverty - An Empirical Study of Long-Term Recipients of Social Assistance, Social Welfare, Dr. Rosario Laratta (Ed.), InTech, DOI: 10.5772/37833. Available from: http://www.intechopen.com/books/social-welfare/autonomy-and-poverty

Levine, D. and A. Rizvi, (2005), Poverty, Work and Freedom: Political Economy and the Moral Order, Cambridge University Press, Cambridge, UK dalam Situs https://books.google.co.id/ books?id

Lundvall, Bengt-Åke (ed.). (1992). National Innovation Systems: Towards a Theory of Innovation and Interactive Learning. London. Pinter Publishers.

Uriona, Mauricio, At all (2012), A Preliminary Model of Innovation Systems, www.systemdynamics. org/ conferences/.

Rogers, Everett, M. (2003). Diffusions of Innovations; Fifth Edition. Simon \& Schuster Publisher

Suurs, Roald A.A. (2009), Motors of Sustainable Innovation : Towards a Theory on the Dynamics of Technological Innovation Systems. Utrecht University. Utrecht. http://igiturarchive.library.uu.nl/dissertations/2009-0318-201903/suurs.pdf.

Taufik, Tatang A. 2005. Pengembangan Sistem Inovasi Daerah: Perspektif Kebijakan. Pusat Pengkajian Kebijakan Teknologi Pengembangan Unggulan Daerah dan Peningkatan Kapasitas Masyarakat. Jakarta : Diterbitkan oleh Pusat Pengkajian Kebijakan Teknologi Pengembangan Unggulan Daerah dan Peningkatan Kapasitas Masyarakat, Deputi Bidang Pengkajian Kebijakan Teknologi, Badan Pengkajian dan Penerapan Teknologi bekerjasama dengan Deputi Bidang Pengembangan Sipteknas, Kementerian Riset dan Teknologi, 2005.

Iizuka, Michiko, 2013, Innovation systems framework: still useful in the new global context?, UNUMERIT Working Paper Series, United Nations Unversity.

Asian Briefing.11 september 2013. Asia Improves International Competitiveness, dalam Situs: http://www.asiabriefing.com/news/2013/09/asia-improves-international-competitiveness/ 